\title{
Dietary patterns among British adults: compatibility with dietary guidelines for salt/sodium, fat, saturated fat and sugars
}

\author{
Sigrid Gibson ${ }^{1, *}$ and Margaret Ashwell ${ }^{2}$ \\ ${ }^{1}$ SiG-Nurture Ltd, 11 Woodway, Guildford, Surrey, GU1 2TF, UK: ${ }^{2}$ Ashwell Associates (Europe) Ltd, Ashwell \\ Street, Ashwell, Hertfordshire, SG7 5PZ, UK
}

Submitted 15 September 2010: Accepted 15 March 2011: First published online 6 May 2011

\begin{abstract}
Objective: To examine dietary patterns among British adults, associations with $\mathrm{Na}$ and macronutrient intakes, and implications for dietary advice.

Design: Principal component analysis of $7 \mathrm{~d}$ weighed dietary records.

Subjects: Adults aged 19-64 years ( $n$ 1724).

Setting: National Diet and Nutrition Survey (2000/2001).

Results: High Na intake was associated with more energy-dense diets, higher in fat and SFA (percentage of energy) but lower in non-milk extrinsic sugars (NMES). Eight patterns (PC1 to PC8) explained $40 \%$ of the total variance in food intakes. Three patterns - PC3 (high loadings on bread, fats and cheese), PC2 (meat products, eggs and chips) and PC7 (red meat, sauces and alcohol) - were associated with high $\mathrm{Na}$ intake. Of these, PC3 correlated with high Na density and Na:K ratio, while PC2 correlated with fat. By contrast, three patterns - 'health-conscious' (PC1; vegetables, fruit, fruit juice, fish), 'breakfast cereals and milk' (PC6) and 'chicken and rice' (PC8) - were associated with modest $\mathrm{Na}$ intake, lower $\mathrm{Na}$ density and lower fat and SFA. PC2 was positively correlated, and PC1 was negatively correlated, with adding salt to food. Other patterns were 'tea/coffee and cakes' (PC4; associated with high SFA and NMES) and 'soft drinks and snacks' (PC5; associated with high NMES but not fat or SFA). The dietary patterns of males and females differed slightly.

Conclusions: Dietary patterns PC1, PC6, PC8 (vegetables, fruit, fish, milk, breakfast cereals, poultry) were broadly compatible with guidelines for salt, fat, SFA and NMES. However, other patterns tended to be high in either salt or NMES.
\end{abstract}

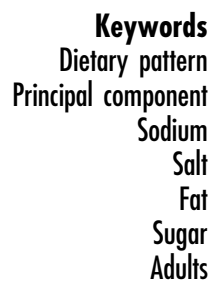

In 1994 the Committee on Medical Aspects of Food and Nutrition Policy reviewed nutritional influences on CVD including the impact of $\mathrm{Na}$ on blood pressure. It recommended a reduction in the population average intake of salt from approximately $9 \mathrm{~g}$ to $6 \mathrm{~g}$ daily for adults ${ }^{(1)}$. This was subsequently reiterated by the Scientific Advisory Committee on Nutrition (SACN) in $2003^{(2)}$, which also set recommendations for salt intakes among children.

The rationale for lowering $\mathrm{Na}$ intake across the population is that this would lead to clinically significant reductions in blood pressure ${ }^{(3)}$, which could have a substantial effect on cardiovascular events and healthcare costs ${ }^{(4)}$. However, the evidence is not without contention and results from meta-analyses have been mixed $^{(5-7)}$. Graudal et al. concluded in 1998 that studies did not support a general recommendation to reduce $\mathrm{Na}$ intake but did support use as a supplementary treatment in hypertension ${ }^{(8)}$. This and other earlier metaanalyses $^{(9,10)}$ have been criticised for including trials of short duration and trials of acute salt loading followed by severe depletion which does not reflect the 'real-life' situation. A more recent meta-analysis of eleven trials lasting more than 4 weeks among individuals with normal blood pressure reported that a $4.4 \mathrm{~g}$ reduction in mean salt intake was associated with a $2 \mathrm{mmHg}$ reduction in systolic and a $1 \mathrm{mmHg}$ reduction in diastolic blood pressure $^{(4)}$. The effect for people with hypertension was greater $(5 \mathrm{mmHg}$ and $2.7 \mathrm{mmHg}$ for systolic and diastolic blood pressure, respectively). Similar results were reported in a Cochrane review by Jurgens and Graudal, who concluded that longer-term trials of effects on metabolic variables, morbidity and mortality are required ${ }^{(7)}$. Results from the randomised Trials of Hypertension Prevention over 10-15 years have reported that a very-low-salt diet reduced cardiovascular events by $25-30 \%^{(11)}$ and it has been claimed that $\mathrm{Na}$ reduction may have benefit independent of its impact on hypertension ${ }^{(12,13)}$.

Salt $(\mathrm{NaCl})$ in the diet derives from three sources: (i) discretionary salt (added at the table or in cooking); (ii) salt naturally present in food and water; and 
(iii) salt added in food processing. These are estimated to account for approximately 15\%, 15\% and 70\%, respectively, of the total salt consumed ${ }^{(14)}$. The SACN report suggested that reduction in the average salt intake would be best achieved using a population-based approach through the adoption of a healthy balanced diet, low in salt and fat and rich in fruit, vegetables and complex carbohydrates. Since approximately $75 \%$ of total salt was estimated to be derived from processed foods ${ }^{(15)}$, significant reductions in the $\mathrm{Na}$ content of processed foods were needed, requiring the cooperation of industry ${ }^{(2)}$. Accordingly, in March 2006 the Food Standards Agency published the (voluntary) salt reduction targets for 2010 and in May 2009 issued revised salt reduction targets for $2012^{(16)}$, which were even more challenging than the previous targets for 2010. The food industry has reformulated many products to reduce salt content. However current intakes among adults (based on $\mathrm{Na}$ excretion) are still estimated to be about $8.6 \mathrm{~g} / \mathrm{d}^{(17)}$, in excess of the population target of $6 \mathrm{~g} / \mathrm{d}$. For labelling purposes $1 \mathrm{~g} \mathrm{Na}$ is equivalent to $2.5 \mathrm{~g}$ salt.

Ongoing monitoring of $\mathrm{Na}$ intake and $\mathrm{Na}$ levels in foods is required to assess progress towards the targets. The SACN report also identified the need to improve the existing evidence base, particularly on how patterns of $\mathrm{Na}$ vary across and within population groups and the contribution of home-prepared foods and meals out ${ }^{(2)}$. Dietary patterns give more insights into real-life conditions and may have a greater effect on health outcomes than amounts of individual foods or nutrients ${ }^{(18)}$. Principal component analysis (PCA) is an established multivariate technique to reduce food consumption data to a smaller number of underlying factors or dietary patterns ${ }^{(19,20)}$. These patterns are uncorrelated with each other and explain variations in food intake across a population. In the present study, PCA was used to identify dietary patterns in the National Diet and Nutrition Survey (NDNS) of adults. These patterns were related to indicators of dietary quality, including but not limited to salt intake, with the intention of helping to inform dietary strategies for improved public health nutrition. We hypothesised that a 'healthy eating' pattern (high in fruit/ vegetables/fish) was likely to be low in salt and that a high relative consumption of bread, cheese and meat products was likely to be high in salt and might be associated with other CVD risk factors.

\section{Methods}

\section{Data sets}

Computerised files from the NDNS for adults aged 19 to 64 years were obtained from the UK Data Archive (www.data-archive.ac.uk). The NDNS surveyed a nationally representative sample of adults living in private households in Great Britain, selected using a multistage random probability design with postal sectors as first-stage units. Fieldwork covered a 12-month period in 2000/2001 to cover any seasonality in eating behaviour and in the nutrient content of foods. Overall, $61 \%$ of the eligible sample ( $n$ 3704) completed the dietary interview (responding sample, $n$ 2251) and $77 \%$ of those who completed the dietary interview completed a full $7 \mathrm{~d}$ weighed dietary record (diary sample, $n 1724$, representing $>12000$ person-days of data $)^{(21)}$. Following the diary period, anthropometric and blood pressure measurements were taken from consenting respondents and a $24 \mathrm{~h}$ urine sample collected ( $n$ 1379).

\section{Data analysis}

The NDNS contains data on more than 7000 foods, aggregated into 115 food groups, which for the present study were further aggregated into thirty-four larger food groups. Foods that made a minor contribution to $\mathrm{Na}$ intake (e.g. fruits) or those that had similar $\mathrm{Na}$ content (e.g. breads) were combined to avoid large numbers of spurious comparisons. At the same time, separate categories for types of meat and meat products (sausages, burgers, pies) and other items such as baked beans, pasta, pizza and rice were retained. The NDNS data files include information on the $\mathrm{Na}$ content of each food item consumed, calculated from the nutrient databank linked to the survey. Quantities of the thirty-four food groups consumed and their contribution to $\mathrm{Na}$ intake were calculated on an absolute basis ( $\mathrm{g}$ or $\mathrm{mg}$ per day) and also on an energy-adjusted basis ( $\mathrm{g}$ or $\mathrm{mg}$ per MJ of total diet).

\section{Statistical methods}

All analyses were performed using the PASW Statistics 18 statistical software package (SPSS Inc., Chicago, IL, USA). Differences in food and nutrient intakes according to level of $\mathrm{Na}$ intake were assessed using the Kruskal-Wallis test (non-parametric ANOVA) and the pairwise comparison test with Bonferroni correction (shown in tables in the form $1<2<3$ denoting low $<$ medium $<$ high).

PCA uses the degree to which foods are correlated with each other to derive a new set of variables which are composites. These can be thought of as discrete patterns, as they are uncorrelated with each other. Individuals then have a score on each dietary pattern corresponding to the extent to which their unique food selection deviates from it. Food amounts are standardised so that those with larger variance do not have undue influence. PCA produces as many components as there are food variables but the first few explain proportionally more of the variance in the data. The convention is to choose those with eigenvalues above 1 and/or use a scree plot and/or assess the interpretability of different solutions ${ }^{(22)}$.

Prior to conducting PCA, Barlett's test of sphericity and the Kaiser-Meyer-Olkin (KMO) measure of sampling adequacy $(\mathrm{KMO}=0 \cdot 67$ ) was used to confirm that there were relationships between the food variables and that the analysis should yield distinct and reliable patterns ${ }^{(23)}$. 
Using the intake data on all thirty-four food groups $(\mathrm{g} / \mathrm{d})$ we first extracted all components with an eigenvalue $>1$ and then used the scree plot to select the number to retain. Since there were no clear grounds for preferring six, eight or twelve components, we explored all three solutions, using varimax rotation to maximise separation. The eight-component solution was chosen as offering the best compromise between parsimony and ability to explain a sufficient proportion of the variance (40\%). Components were then interpreted on the basis of their correlations with food groups (loadings). Foods with loadings $>0 \cdot 30$ were considered as contributing significantly to a pattern. The robustness of the analysis was also checked by examining PCA conducted first for men and women separately and second on a random $50 \%$ sample.

Individuals' scores on each factor were calculated by the Anderson-Rubin method, which produces scores that are uncorrelated and standardised (mean of zero and standard deviation of 1). Pearson's correlation coefficients were calculated between adults' factor scores and nutrient intakes to identify patterns associated with $\mathrm{Na}$ intake and dietary Na density. Age and sociodemographic profile of patterns were assessed by comparing mean factor scores across categories of age, social class, region, smoking habit and discretionary salt use, with adjustment for multiple comparisons (Bonferroni correction). All tests were considered significant at $P<0 \cdot 05$.

\section{Results}

The majority of low salt consumers $(<6 \mathrm{~g} / \mathrm{d})$ were women (81\%) and the majority of high salt consumers ( $\geq 8 \mathrm{~g} / \mathrm{d})$ were men (79\%); this reflects the nature of the salt recommendations which are absolute, rather than proportional, to total food or energy intake. There was no significant difference in mean age or age distribution between low, medium and high salt consumers. A high proportion of each age group reported adding salt in cooking $(62-72 \%)$, but more low salt consumers reported never adding salt at the table ( $31 \% v .22 \%$ high of consumers).

High salt consumers tended to eat more food overall, including low-salt foods such as milk and vegetables. Mean and median consumption of bread, spreads and bacon/ham were two to three times higher in those consuming $\geq 8 \mathrm{~g}$ salt $/ \mathrm{d}$ than among low consumers ( $<6 \mathrm{~g}$ salt/d; Appendix 1).

On an energy-adjusted basis (g food/MJ diet), high salt consumers of both sexes ate proportionately more bread, biscuits and cakes, fats, bacon/ham and baked beans, while men who were high consumers also ate relatively more cheese, sausages, sauces and savoury snacks. Conversely, low salt consumers consumed more beverages and vegetables relative to their energy intake (Appendix 2).

Bread was the largest single contributor to total $\mathrm{Na}$ intake, providing about $22 \%$ of $\mathrm{Na}$ for men and $21 \%$ for women (Appendix 3). Other major sources were bacon and ham ( $9 \%$ and $7 \%$ for men and women, respectively) and other meat products such as sausages and pies, while chicken and turkey dishes also contributed more than $5 \%$. Sauces (gravy, ketchup, mayonnaise, etc.) contributed approximately $5 \%$ of all $\mathrm{Na}$, as did breakfast cereals, although this group includes porridge with salt. Excluding porridge, the contribution from other ready-toeat breakfast cereals in 2000/2001 was $4 \cdot 2 \%$.

Increased consumption of salt was associated with increased dietary energy density and $\mathrm{Na}$ density. High salt consumers ( $\geq 8 \mathrm{~g} / \mathrm{d})$ had diets with a higher percentage of energy from fat and SFA (Table 1). Conversely low salt consumers $(<6 \mathrm{~g} / \mathrm{d})$ tended to have diets higher in nonmilk extrinsic sugars (NMES; $P<0.05$ among men only). Low salt consumers had recorded $\mathrm{Na}$ intakes that averaged only $61-67 \%$ of $\mathrm{Na}$ excretion, compared with 86-91\% among high salt consumers.

Table 1 Mean energy and nutrient intakes according to level of salt intake: adults aged 19-64 years ( $n$ 1724), National Diet and Nutrition Survey $(2000 / 2001)$

\begin{tabular}{|c|c|c|c|c|c|c|c|c|}
\hline & \multicolumn{4}{|c|}{ Men } & \multicolumn{4}{|c|}{ Women } \\
\hline & \multicolumn{3}{|c|}{ Salt intake } & \multirow{2}{*}{$\begin{array}{c}\text { Multiple } \\
\text { comparison test }\end{array}$} & \multicolumn{3}{|c|}{ Salt intake } & \multirow{2}{*}{$\begin{array}{c}\text { Multiple } \\
\text { comparison test } \dagger\end{array}$} \\
\hline & $<6 \mathrm{~g} / \mathrm{d}$ & $6-8 \mathrm{~g} / \mathrm{d}$ & $\geq 8 \mathrm{~g} / \mathrm{d}$ & & $<6 \mathrm{~g} / \mathrm{d}$ & $6-8 \mathrm{~g} / \mathrm{d}$ & $\geq 8 \mathrm{~g} / \mathrm{d}$ & \\
\hline$n$ & 134 & 249 & 383 & & 571 & 286 & 101 & \\
\hline Age of respondent (years) & 43 & 43 & 41 & NS & 42 & 42 & 41 & NS \\
\hline Na intake $(\mathrm{mg} / \mathrm{d})$ & 1893 & 2803 & 4069 & $1<2<3$ & 1852 & 2713 & 3655 & $1<2<3$ \\
\hline Dietary Na density (mg/MJ) & 287 & 324 & 371 & $1<2<3$ & 317 & 364 & 414 & $1<2<3$ \\
\hline Dietary Na:K ratio & 0.79 & 0.92 & $1 \cdot 11$ & $1<2<3$ & 0.82 & 0.98 & $1 \cdot 19$ & $1<2<3$ \\
\hline Energy intake $(\mathrm{MJ} / \mathrm{d})$ & $6 \cdot 92$ & 8.96 & $11 \cdot 14$ & $1<2<3$ & $6 \cdot 06$ & $7 \cdot 66$ & $9 \cdot 07$ & $1<2<3$ \\
\hline Energy density $(\mathrm{kJ} / \mathrm{q})$ & 2.97 & $3 \cdot 28$ & 3.43 & $1<2<3$ & $2 \cdot 84$ & 3.06 & $3 \cdot 35$ & $1<2<3$ \\
\hline$\%$ of energy from fat & 31 & 34 & 34 & $1<3$ & 33 & 34 & 35 & $1<2<3$ \\
\hline$\%$ of energy from SFA & 11 & 13 & 13 & $1<2,3$ & 12 & 13 & 13 & $1<3$ \\
\hline$\%$ of energy from NMES & 15 & 12 & 12 & $1<2,3$ & 12 & 11 & 11 & $1<3$ \\
\hline Urinary $\mathrm{Na}(\mathrm{mg})$ & 3117 & 3869 & 4746 & $1<2<3$ & 2844 & 3098 & 4006 & $1<2<3$ \\
\hline
\end{tabular}

NMES, non-milk extrinsic sugars.

tBonferroni correction. 


\section{Principal component analysis of food patterns}

In the total sample, eight patterns (components) accounted for $40 \%$ of the total variance in food intakes. They were interpreted as follows, based on the foods with which they were most highly correlated:

1. 'health-conscious' (high in vegetables, fruit, water and fish);

2. 'chips, meat products and eggs' (including sausages, meat pies and baked beans);

3. 'bread, fat spread and cheese';

4. 'coffee/tea and cakes' (hot beverages, sugar, confectionery, biscuits and cakes);

5. 'soft drinks and snacks' (soft drinks, pizza, pasta and savoury snacks);

6. 'breakfast cereal and milk';

7. 'red meat and alcohol' (including sauces);

8. 'chicken and rice'.

Table 2 gives the correlation coefficients (factor loadings) for the top eight patterns with the individual foods, where coefficients are greater than $0 \cdot 30$. Table 3 shows their correlations with energy and nutrient intakes, $\mathrm{Na}$ density and excretion, blood pressure, anthropometric measurements and reported use of salt at the table. All correlations were adjusted for age.

In line with the hypothesis, PC1 (health-conscious) was inversely correlated with the $\mathrm{Na}: \mathrm{K}$ ratio of the diet. Conversely, PC2 (chips, meat products and eggs), PC7 (red meat and alcohol) and especially PC3 (bread, fat spread and cheese) were associated with high salt intake, while PC3 was also associated with higher $\mathrm{Na}$ density (mg/MJ diet) and $\mathrm{Na}: \mathrm{K}$ ratio. Correlations with fat were highest for PC2 (positive) and PC6 (breakfast cereal and milk; negative). PC4 (coffee/tea and cakes) was most highly correlated with SFA and NMES, but inversely correlated with dietary Na density. PC5 (soft drinks and snacks) was associated with high NMES but not fat or SFA. There were weak trends with discretionary salt use; positive for PC2 and negative for PC1. Finally the three patterns associated with high $\mathrm{Na}$ intake (PC2, PC3, PC7) were weakly correlated with urinary $\mathrm{Na}$, while $\mathrm{PC} 7$ was also correlated with waist circumference and (weakly) with blood pressure.

Figures 1 and 2 display the correlations with $\mathrm{Na}$ intake and dietary $\mathrm{Na}$ density for each of the dietary patterns (data from Table 3).

Additional PCA were run for men and women separately, using the same extraction criterion (eight factors). Similar but not identical patterns, including a 'healthconscious' pattern, a 'bread and spread' pattern, a 'hot drinks and sweets' pattern and a 'soft drinks and savoury snacks' pattern were observed in both (Tables 4 and 5). Among both men and women, the bread and spread pattern was most highly correlated with $\mathrm{Na}$ intake, $\mathrm{Na}$ density and $\mathrm{Na}: \mathrm{K}$ ratio and also with SFA. The healthconscious pattern (and to a lesser extent the "cereals and milk, chicken' pattern among men) was inversely correlated with fat, SFA, NMES and Na:K ratio. The pattern characterised by hot beverages, milk and sugar or cakes tended to be high in SFA and NMES but of low Na density.

Some individual food groups clustered differently. For example, breakfast cereals were associated with the healthconscious pattern among women, but were in a separate pattern among men. Similarly, bacon/ham, sausages, eggs and chips were clustered together for men, but this pattern was less apparent for women (bacon/ham being associated with bread). The groups featuring breakfast cereals tended to conform to dietary guidelines while those with meat products tended to be high in $\mathrm{Na}$, fat and SFA.

Tables 6 and 7 show the correlations of the sex-specific dietary patterns with energy and nutrient intakes, Na density and excretion, blood pressure and anthropometric measurements (all correlations were adjusted for age).

Results on the random 50\% sample with a sixcomponent solution (data not shown) also yielded patterns that could be interpreted as 'health-conscious', 'bread/ spread/bacon/ham', 'hot beverages, milk and sugar', soft drinks/savoury snacks/pizza', 'meat pies, sausages, eggs and chips' and 'chicken and rice'.

\section{Discussion}

Analysis of dietary patterns takes account of the multidimensional nature of food habits as practised in the population. It therefore has the potential to provide a more realistic basis for dietary advice, complementing approaches based on the contribution of foods to the average diet. It may also highlight the compatibility or otherwise of multiple dietary guidelines. An increasing number of epidemiological studies are favouring PCA or factor analysis to explore patterns within the data set and relate these to other variables. Many find a 'healthy' or 'prudent' pattern contrasted with a 'traditional' or 'Western' pattern ${ }^{(22,24-27)}$. Studies in adolescents and children tend to find fewer patterns explaining more of the variance, suggesting a more limited variety of intakes among this age group than is observed among adults ${ }^{(26,28)}$.

The results of the present study compare well with the analysis of the German Potsdam cohort of the European Investigation into Cancer and Nutrition, in which seven patterns (factors) explained $31 \%$ of the variance and a bread and sausage pattern was associated with high salt intake $^{(29)}$. In a study of incident hypertension among women in the same cohort ${ }^{(30)}$, there was an (inverse) association with a 'DASH-type' (18) $\operatorname{diet}$ (Dietary Approaches to Stop Hypertension; fruit, vegetables and milk products) but no significant association with either the 'traditional cooking' pattern or the 'fruits and vegetables' pattern after adjustment for potential confounders. Several studies investigating dietary patterns in both sexes have found slight differences between men and women but major patterns that were common to both ${ }^{(29-32)}$. 
Table 2 Correlation of dietary patterns obtained from principal component analysis with foods (correlations less than 0.30 not shown): all men and women ( $n$ 1724), National Diet and Nutrition Survey (2000/2001)

\begin{tabular}{|c|c|c|c|c|c|c|c|c|}
\hline & $\begin{array}{c}\text { PC1 } \\
\text { Health- } \\
\text { conscious }\end{array}$ & $\begin{array}{c}\text { PC2 } \\
\text { Chips, meat } \\
\text { products and } \\
\text { eggs }\end{array}$ & $\begin{array}{c}\text { PC3 } \\
\text { Bread, fat } \\
\text { spread and } \\
\text { cheese }\end{array}$ & $\begin{array}{c}\text { PC4 } \\
\begin{array}{c}\text { Tea/coffee and } \\
\text { cakes }\end{array}\end{array}$ & $\begin{array}{c}\text { PC5 } \\
\text { Soft drinks and } \\
\text { snacks }\end{array}$ & $\begin{array}{c}\text { PC6 } \\
\begin{array}{l}\text { Breakfast cereal } \\
\text { and milk }\end{array}\end{array}$ & $\begin{array}{c}\text { PC7 } \\
\text { Red meat and } \\
\text { alcohol }\end{array}$ & $\begin{array}{c}\text { PC8 } \\
\text { Chicken and rice }\end{array}$ \\
\hline Vegetables & $0 \cdot 68$ & & & & & & & \\
\hline Fruit & 0.61 & & & & & & & \\
\hline Puddings, yoghurt \& ice cream & 0.49 & & & & & $0 \cdot 35$ & & \\
\hline Fish & $0 \cdot 46$ & & & & -0.32 & & & \\
\hline Water & 0.40 & & & & & & & \\
\hline Fruit juice & $0 \cdot 38$ & & & & & & & $0 \cdot 35$ \\
\hline Chips \& fried potatoes & & $0 \cdot 62$ & & & & & & \\
\hline Sausages & & $0 \cdot 42$ & & & & & $0 \cdot 34$ & \\
\hline Meat pies & & 0.41 & & & & & & \\
\hline Eggs & & $0 \cdot 36$ & & & & & & \\
\hline Baked beans & & $0 \cdot 33$ & & & & & & \\
\hline Soup & & -0.31 & & & & & & \\
\hline Burgers \& kebabs & & & & & & & & \\
\hline Bread & & & $0 \cdot 76$ & & & & & \\
\hline Fat spreads & & & 0.74 & & & & & \\
\hline Cheese & & & 0.48 & & & & & \\
\hline Other cereal products & & & -0.34 & & & & & \\
\hline Sugar, preserves \& confectionery & & & & 0.66 & & & & \\
\hline Beverages (hot) & & & & 0.66 & -0.31 & & & \\
\hline Biscuits, cakes \& pastries & & & & 0.46 & & & & \\
\hline Soft drinks & & $0 \cdot 32$ & & & 0.62 & & & \\
\hline Pizza & & & & & 0.49 & & & \\
\hline Pasta & & -0.38 & & & 0.44 & & & \\
\hline Savoury snacks & & & & & 0.44 & & & \\
\hline Breakfast cereal & & & & & & $0 \cdot 74$ & & \\
\hline Milk & & & & 0.41 & & 0.66 & & \\
\hline Red meat & & & & & & & 0.55 & \\
\hline Alcoholic drinks & & & & & & & 0.45 & \\
\hline Sauces & $0 \cdot 36$ & & & & 0.34 & & 0.43 & \\
\hline Bacon/ham & & 0.34 & & & & & 0.38 & \\
\hline Other meat \& offal & & & & & & & 0.34 & \\
\hline Rice & & & & & & & & 0.74 \\
\hline Chicken \& turkey & & & & & & $0 \cdot 41$ & & 0.58 \\
\hline Other potatoes & & & & & & & $0 \cdot 31$ & -0.45 \\
\hline$\%$ of variance explained & $6 \cdot 4$ & $5 \cdot 6$ & $5 \cdot 3$ & $5 \cdot 1$ & $4 \cdot 8$ & $4 \cdot 7$ & $4 \cdot 5$ & $4 \cdot 3$ \\
\hline
\end{tabular}


The results of the present study should be generalisable to the British adult free-living population. The NDNS sampling frame was designed to be nationally representative of adults in private households and those who completed the dietary record had a similar demographic profile by sex, age and social class to those interviewed. Furthermore, a separate investigation concluded that there was no serious evidence of non-response bias ${ }^{(21)}$.

Inevitably, there are some limitations of the data and caveats are required. First, all estimates of total $\mathrm{Na}$ intake based on food records tend to underestimate true consumption because discretionary sources are not included and under-reporting of food intake is common. Comparison with urinary $\mathrm{Na}$ in the present study can only comprise partial validation because the single $24 \mathrm{~h}$ urine collection was made subsequent to the dietary records. However, other measurements of $\mathrm{Na}$ excretion indicate that underestimation in diet records is of the order of $25-30 \%{ }^{(17)}$. Therefore the present analysis overestimates the relative contribution of processed foods to $\mathrm{Na}$ intake in comparison to the discretionary sources. Second, estimates of the contribution from different food groups are limited by the inability to disaggregate composite dishes. For example, lasagne or shepherd's pie is classified as a meat dish, resulting in some overestimation of the $\mathrm{Na}$ contribution from meat and underestimation of the contribution from the sauce, vegetables, etc. Third, with regard to the dietary pattern analysis it is inevitable that use of different food groupings, extraction criteria and rotations can all influence results and that interpretation or naming of the components involves an element of subjectivity. Our separate analysis of men and women confirms other work suggesting that dietary patterns may be common to both but there are also subtle differences, which may deserve further study.

Significant reductions in $\mathrm{Na}$ content of foods have been achieved in manufactured foods since these data were collected in 2000 and this needs to be taken into account in interpreting the results in the current context. In particular, the Na content of branded breakfast cereals has declined by approximately $44 \%$ since 2000 and reductions have also been made by industry for sliced bread $(\sim 30 \%)$, cakes and biscuits (15-50\%), savoury snacks (up to 50\%), sauces and soups (25-30\%) and some processed cheeses ${ }^{(16)}$. In terms of the dietary patterns identified in the present study, this implies that the breakfast cereal and milk pattern would today be more strongly associated with lower $\mathrm{Na}$ intake, $\mathrm{Na}$ density and $\mathrm{Na}: \mathrm{K}$ ratio, while the positive association of the bread, fat spread and cheese pattern might be slightly attenuated. Clearly, it would be desirable to conduct similar dietary pattern analyses on new data from the rolling NDNS programme once the sample size is sufficient.

Since dietary survey data do not capture all sources of $\mathrm{Na}$, progress towards achievement of salt guidelines is best assessed from measures of urinary $\mathrm{Na}$ excretion. These confirm that mean salt intake among adults has declined 


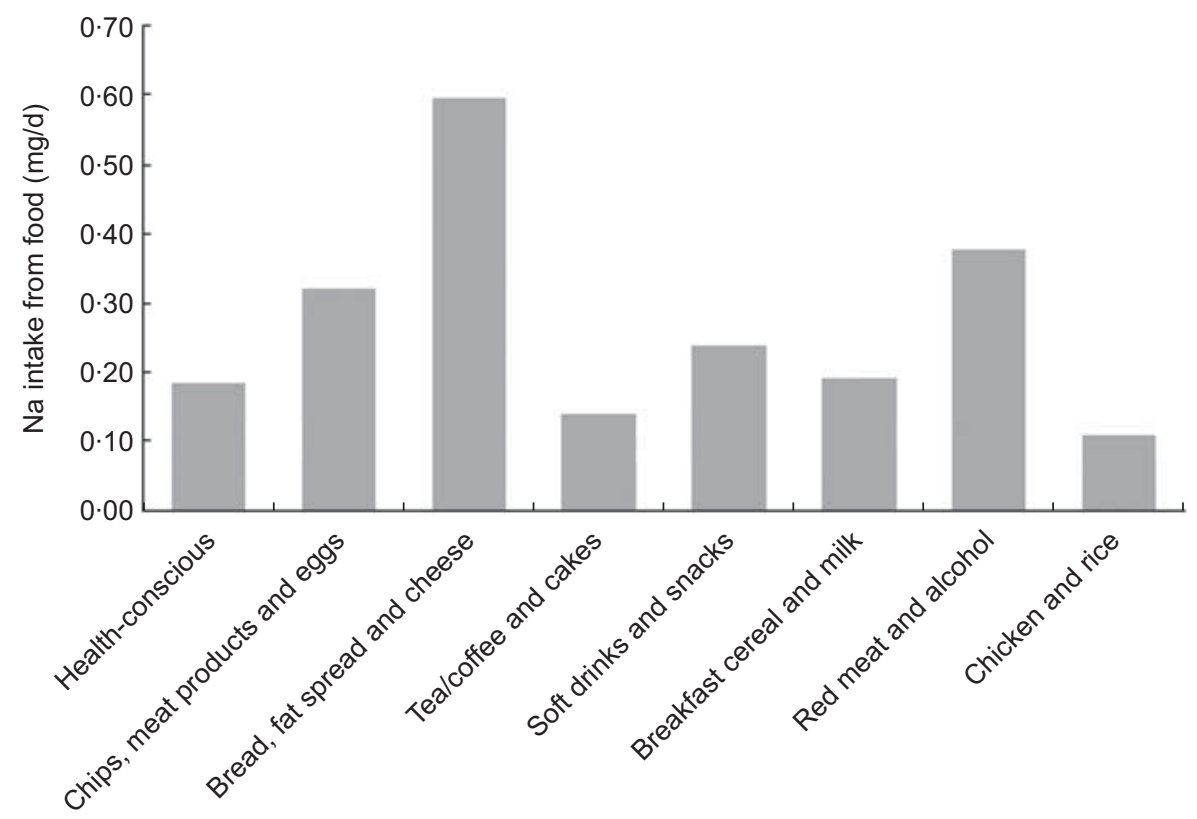

Fig. 1 Dietary patterns from principal component analysis and their correlation with sodium intake: adults aged 19-64 years ( $n$ 1724), National Diet and Nutrition Survey (2000/2001)

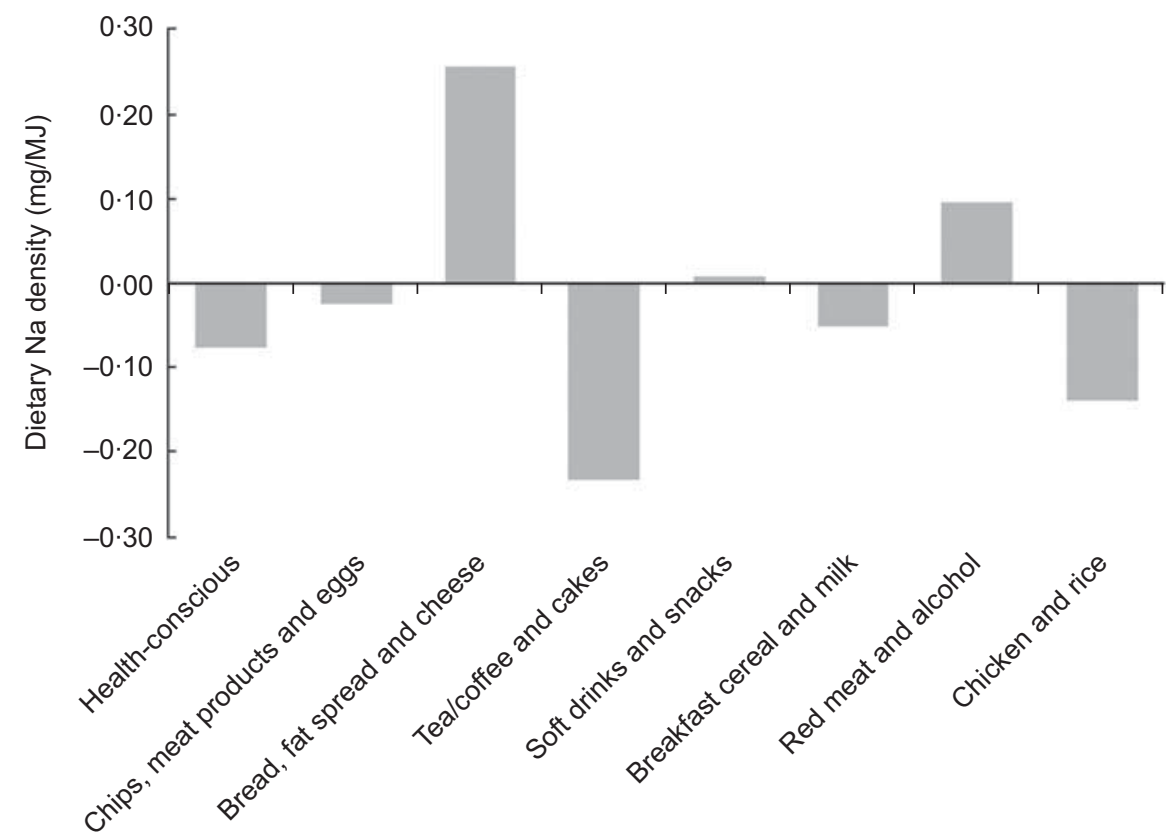

Fig. 2 Dietary patterns from principal component analysis and their correlation with dietary sodium density: adults aged 19-64 years ( $n$ 1724), National Diet and Nutrition Survey (2000/2001)

from $9.5 \mathrm{~g} / \mathrm{d}$ to $8.6 \mathrm{~g} / \mathrm{d}$ in 2008 (a $10 \%$ reduction) ${ }^{(17)}$. Clearly there is some way to go to achieve $6 \mathrm{~g} / \mathrm{d}$ (or less) as a population mean, while ambitions to apply this goal to individuals or to reduce it still further look unlikely to be achieved in the short term. However, if the reformulation successes of many cereal products and savoury snacks were replicated across the spectrum of processed foods, the $6 \mathrm{~g} / \mathrm{d}$ goal could be achieved providing that consumers do not compensate by increasing their use of salt in cooking or at the table. Reductions in salt content of processed foods to date would seem to predict a steeper fall in $\mathrm{Na}$ excretion than has been observed in practice (10\%) and the reasons for this discrepancy are not entirely clear. There is to our knowledge no reliable data on discretionary salt consumption and there may be a need to better understand the impact of influences, such as celebrity chefs, meals out, home cooking $v$. ready meals and the popularity of spices and condiments, on this aspect of salt intake. 
Table 4 Correlation of dietary patterns obtained from principal component analysis with foods (correlations less than 0.30 not shown): men only ( $n$ 766), National Diet and Nutrition Survey $(2000 / 2001)$

\begin{tabular}{|c|c|c|c|c|c|c|c|c|}
\hline & $\begin{array}{c}\text { PC1 } \\
\text { Health-conscious } \\
\text { (fruit, vegetables } \\
\text { and fish) }\end{array}$ & $\begin{array}{c}\text { PC2 } \\
\begin{array}{c}\text { Bread, spread } \\
\text { and cheese }\end{array}\end{array}$ & $\begin{array}{c}\text { PC3 } \\
\text { Cakes, sugar } \\
\text { and beverages } \\
\end{array}$ & $\begin{array}{c}\text { PC4 } \\
\text { Meat products, } \\
\text { chips and eggs }\end{array}$ & $\begin{array}{l}\text { PC5 } \\
\text { Cereals and } \\
\text { milk, chicken } \\
\end{array}$ & $\begin{array}{c}\text { PC6 } \\
\text { Soft drinks, pizza } \\
\text { and savoury } \\
\text { snacks }\end{array}$ & $\begin{array}{c}\text { PC7 } \\
\begin{array}{c}\text { Other meat and } \\
\text { potatoes }\end{array}\end{array}$ & $\begin{array}{c}\text { PC8 } \\
\begin{array}{c}\text { Red meat and } \\
\text { sauces }\end{array} \\
\end{array}$ \\
\hline Fruit juice & 0.58 & & & & & & & \\
\hline Vegetables & 0.58 & & & & & & & \\
\hline Fish & 0.53 & & & & & & & \\
\hline Fruit & 0.52 & & 0.34 & & & & & \\
\hline Water & 0.37 & & & & 0.30 & & & \\
\hline Meat pies & -0.32 & & & & & & & \\
\hline Bread & & $\begin{array}{l}0.79 \\
0.78\end{array}$ & & & & & & \\
\hline $\begin{array}{l}\text { Fat spreads } \\
\text { Cheese }\end{array}$ & & $\begin{array}{l}0.78 \\
0.52\end{array}$ & & & & & & \\
\hline Biscuits, cakes \& pastries & & & 0.60 & & & & & \\
\hline Alcoholic drinks & & & -0.54 & & & & & \\
\hline $\begin{array}{l}\text { Puddings, yoghurt \& ice cream } \\
\text { Sugar. presenves \& confectionery }\end{array}$ & $\begin{array}{r}0.37 \\
-0.45\end{array}$ & & 0.50 & & & & & \\
\hline Chips \& fried potatoes & & & & 0.58 & & & & \\
\hline Bacon/ham & & & & 0.48 & & & & \\
\hline Sausages & & & & 0.47 & & & & \\
\hline Eggs & & & & 0.46 & & & & \\
\hline $\begin{array}{l}\text { Pasta } \\
\text { Soup }\end{array}$ & & & & $-0 \cdot 41$ & & & & \\
\hline $\begin{array}{l}\text { Soup } \\
\text { Breakfast cereal }\end{array}$ & & & & & & & & \\
\hline $\begin{array}{l}\text { Breakfast cereal } \\
\text { Milk \& cream }\end{array}$ & & & & & $\begin{array}{l}0.78 \\
0.65\end{array}$ & & & \\
\hline Chicken \& turkey & & & & & $\begin{array}{l}0.65 \\
0.60\end{array}$ & & & \\
\hline Soft drinks & & & & & & 0.71 & & \\
\hline Pizza & & & & & & 0.57 & & \\
\hline Beverages & -0.37 & & 0.40 & & & $-0 \cdot 40$ & 0.30 & \\
\hline $\begin{array}{l}\text { Savoury snacks } \\
\text { Burgers \& kebabs }\end{array}$ & & & & & & 0.34 & & \\
\hline Rice & & & & & & & -0.60 & 0.37 \\
\hline Other potatoes & & & & & & & 0.52 & \\
\hline $\begin{array}{l}\text { Other meat } \& \text { offal } \\
\text { Baked beans }\end{array}$ & & & & & & & 0.46 & \\
\hline $\begin{array}{l}\text { Baked beans } \\
\text { Red meat }\end{array}$ & & & & & & & & 0.70 \\
\hline Sauces & & & & & & 0.31 & & 0.39 \\
\hline Other cereal products & & & & & & & & \\
\hline$\%$ of variance explained & $6 \cdot 8$ & $5 \cdot 8$ & $5 \cdot 5$ & $5 \cdot 3$ & $5 \cdot 2$ & $5 \cdot 1$ & $4 \cdot 4$ & $4 \cdot 2$ \\
\hline
\end{tabular}


Table 5 Correlation of dietary patterns obtained from principal component analysis with foods (correlations less than $0 \cdot 30$ not shown): women only ( $n$ 958), National Diet and Nutrition Survey (2000/2001)

\begin{tabular}{|c|c|c|c|c|c|c|c|c|}
\hline & $\begin{array}{c}\text { PC1 } \\
\text { Health-conscious (fruit, } \\
\text { vegetables, sweet dairy } \\
\text { and cereals) }\end{array}$ & $\begin{array}{c}\text { PC2 } \\
\begin{array}{c}\text { Beverages, milk } \\
\text { and sugar }\end{array}\end{array}$ & $\begin{array}{c}\text { PC3 } \\
\text { Soft drinks and } \\
\text { savoury snacks }\end{array}$ & $\begin{array}{l}\text { PC4 } \\
\text { Bread and } \\
\text { spread }\end{array}$ & $\begin{array}{c}\text { PC5 } \\
\text { Rice and chicken }\end{array}$ & $\begin{array}{l}\text { PC6 } \\
\text { Meat products } \\
\text { and chips }\end{array}$ & $\begin{array}{l}\text { PC7 } \\
\text { Sauces and } \\
\text { alcohol }\end{array}$ & $\begin{array}{l}\text { PC8 } \\
\text { Red meat } \\
\text { avoiders }\end{array}$ \\
\hline Fruit & 0.67 & & & & & & & \\
\hline Puddings, yoghurt \& ice cream & 0.64 & & & & & & & \\
\hline Vegetables & $0 \cdot 61$ & & & & & & $0 \cdot 31$ & \\
\hline Breakfast cereal & 0.49 & & & & & & & \\
\hline Biscuits, cakes \& pastries & $0 \cdot 37$ & & & & & & & \\
\hline Water & 0.33 & & & & & & & \\
\hline Beverages & & 0.73 & & & & & & \\
\hline Milk \& cream & & 0.69 & & & & & & \\
\hline Sugar, preserves \& confectionery & & 0.55 & & & & & & \\
\hline Soft drinks & & & 0.65 & & & & & \\
\hline Savoury snacks & & & 0.55 & & & & & \\
\hline Fish & & & -0.41 & & & & & \\
\hline Soup & & & -0.35 & & & & & \\
\hline Burgers \& kebabs & & & 0.34 & & & & & \\
\hline Fat spreads & & & & $0 \cdot 74$ & & & & \\
\hline Bread & & & & 0.69 & & & & \\
\hline Fruit juice & & & & $0 \cdot 34$ & & & & \\
\hline Eggs & & & & $0 \cdot 32$ & & & & \\
\hline Rice & & & & & 0.69 & & & \\
\hline Chicken \& turkey & & & & & 0.56 & & & \\
\hline Other potatoes & & & & & $-0 \cdot 44$ & & & \\
\hline Cheese & $0 \cdot 33$ & & & & -0.34 & & & \\
\hline Baked beans & & & & & -0.34 & & & \\
\hline Pasta & & & & & & -0.58 & & \\
\hline Meat pies & & & & & & 0.49 & & \\
\hline Other meat \& offal & & & & & & 0.43 & & \\
\hline Chips \& fried potatoes & & & $0 \cdot 36$ & & & 0.38 & & \\
\hline Sauces & & & & & & & $0 \cdot 67$ & \\
\hline Alcoholic drinks & & & & & & & $0 \cdot 46$ & \\
\hline Pizza & & & & & & & -0.37 & \\
\hline Sausages & & & & & & & & \\
\hline Other cereal products & & & & & & & & 0.57 \\
\hline Red meat & & & & & & & & -0.50 \\
\hline Bacon/ham & & & & $0 \cdot 30$ & & & & -0.45 \\
\hline$\%$ of variance explained & $7 \cdot 0$ & $5 \cdot 4$ & $5 \cdot 3$ & $5 \cdot 1$ & $4 \cdot 4$ & $4 \cdot 4$ & $4 \cdot 0$ & $4 \cdot 0$ \\
\hline
\end{tabular}


Table 6 Correlations of dietary patterns obtained from principal component analysis with energy and nutrient intakes, food habits and health indices (adjusted for age): men only ( $n$ 766), National Diet and Nutrition Survey (2000/2001)

\begin{tabular}{|c|c|c|c|c|c|c|c|c|}
\hline & $\begin{array}{c}\text { PC1 } \\
\text { Health-conscious } \\
\text { (fruit, vegetables } \\
\text { and fish) }\end{array}$ & $\begin{array}{c}\text { PC2 } \\
\text { Bread, spread } \\
\text { and cheese }\end{array}$ & $\begin{array}{c}\text { PC3 } \\
\text { Cakes, sugar } \\
\text { and beverages }\end{array}$ & $\begin{array}{c}\text { PC4 } \\
\text { Meat products, } \\
\text { chips and eggs }\end{array}$ & $\begin{array}{l}\text { PC5 } \\
\text { Cereals and } \\
\text { milk, chicken }\end{array}$ & $\begin{array}{c}\text { PC6 } \\
\text { Soft drinks, pizza } \\
\text { and savoury } \\
\text { snacks }\end{array}$ & $\begin{array}{l}\text { PC7 } \\
\text { Other meat and } \\
\text { potatoes }\end{array}$ & $\begin{array}{c}\text { PC8 } \\
\text { Red meat and } \\
\text { sauces }\end{array}$ \\
\hline Energy intake (kJ) & 0.00 & 0.49 & $0 \cdot 30$ & 0.27 & 0.32 & $0 \cdot 21$ & 0.08 & 0.25 \\
\hline Energy density $(\mathrm{kJ} / \mathrm{g})$ & -0.08 & 0.22 & 0.25 & 0.23 & $-0 \cdot 10$ & $0 \cdot 11$ & -0.23 & -0.21 \\
\hline$\%$ of energy from fat & -0.09 & $0 \cdot 20$ & $0 \cdot 13$ & 0.28 & $-0 \cdot 18$ & 0.05 & -0.03 & -0.05 \\
\hline$\%$ of energy from SFA & -0.27 & 0.21 & 0.22 & $0 \cdot 10$ & $-0 \cdot 11$ & $0 \cdot 11$ & $0 \cdot 11$ & -0.09 \\
\hline$\%$ of energy from NMES & -0.33 & -0.22 & 0.36 & -0.07 & -0.09 & 0.02 & -0.02 & -0.04 \\
\hline $\mathrm{Na}$ from food $(\mathrm{mg})$ & 0.07 & 0.67 & $0 \cdot 11$ & 0.28 & $0 \cdot 19$ & 0.22 & $0 \cdot 10$ & 0.23 \\
\hline Dietary $\mathrm{Na}$ density (mg/MJ) & 0.08 & 0.33 & $-0 \cdot 21$ & 0.05 & $-0 \cdot 10$ & 0.04 & 0.05 & 0.04 \\
\hline Dietary Na:K ratio & $-0 \cdot 18$ & 0.51 & $-0 \cdot 11$ & 0.08 & $-0 \cdot 19$ & $0 \cdot 15$ & $-0 \cdot 14$ & -0.06 \\
\hline $\mathrm{BMI}\left(\mathrm{kg} / \mathrm{m}^{2} ; n 723\right)$ & 0.02 & 0.05 & -0.07 & $0 \cdot 14$ & 0.02 & $0 \cdot 13$ & 0.03 & 0.09 \\
\hline Waist circumference (cm) & -0.01 & $0 \cdot 10$ & -0.08 & $0 \cdot 11$ & 0.00 & $0 \cdot 13$ & 0.05 & 0.09 \\
\hline Systolic blood pressure (mmHg; $n$ 717) & -0.07 & -0.01 & $-0 \cdot 16$ & 0.02 & 0.02 & 0.00 & 0.04 & 0.02 \\
\hline Diastolic blood pressure (mmHg) & -0.05 & -0.01 & -0.11 & 0.02 & -0.03 & -0.03 & 0.03 & 0.02 \\
\hline Urinary $\mathrm{Na}(\mathrm{mg} ; n$ 623) & 0.06 & 0.22 & -0.02 & $0 \cdot 19$ & 0.04 & 0.08 & 0.02 & $0 \cdot 14$ \\
\hline
\end{tabular}

NMES, non-milk extrinsic sugars.

Coefficients $(r)>0.10$ were significant at $P<0.01$ and those $>0.20$ were significant at $P<0.0001$.

Table 7 Correlations of dietary patterns obtained from principal component analysis with energy and nutrient intakes, food habits and health indices (adjusted for age): women only ( $n$ 958), National Diet and Nutrition Survey (2000/2001)

\begin{tabular}{|c|c|c|c|c|c|c|c|c|}
\hline & $\begin{array}{c}\text { PC1 } \\
\text { Health-conscious (fruit, } \\
\text { vegetables, sweet dairy } \\
\text { and cereals) }\end{array}$ & $\begin{array}{l}\text { PC2 } \\
\text { Beverages, milk } \\
\text { and sugar }\end{array}$ & $\begin{array}{c}\text { PC3 } \\
\text { Soft drinks and } \\
\text { savoury snacks }\end{array}$ & $\begin{array}{l}\text { PC4 } \\
\text { Bread and } \\
\text { spread }\end{array}$ & $\begin{array}{c}\text { PC5 } \\
\text { Rice and chicken }\end{array}$ & $\begin{array}{l}\text { PC6 } \\
\text { Meat products } \\
\text { and chips }\end{array}$ & $\begin{array}{l}\text { PC7 } \\
\text { Sauces and } \\
\text { alcohol }\end{array}$ & $\begin{array}{l}\text { PC8 } \\
\text { Red meat } \\
\text { avoiders }\end{array}$ \\
\hline Energy intake (kJ) & 0.36 & $0 \cdot 27$ & 0.44 & 0.49 & $0 \cdot 16$ & $0 \cdot 13$ & 0.22 & 0.06 \\
\hline Energy density $(\mathrm{kJ} / \mathrm{g})$ & $-0 \cdot 12$ & -0.05 & 0.36 & 0.24 & $0 \cdot 14$ & $0 \cdot 19$ & -0.23 & -0.03 \\
\hline$\%$ of energy from fat & $-0 \cdot 18$ & 0.05 & $0 \cdot 11$ & 0.32 & 0.02 & 0.33 & 0.00 & 0.08 \\
\hline$\%$ of energy from SFA & $-0 \cdot 16$ & $0 \cdot 15$ & $0 \cdot 15$ & $0 \cdot 29$ & -0.09 & $0 \cdot 26$ & -0.07 & 0.08 \\
\hline$\%$ of energy from NMES & $-0 \cdot 11$ & 0.30 & 0.26 & -0.03 & $0 \cdot 10$ & 0.01 & $-0 \cdot 11$ & $0 \cdot 16$ \\
\hline $\mathrm{Na}$ from food $(\mathrm{mg})$ & 0.22 & 0.07 & 0.28 & 0.52 & 0.00 & $0 \cdot 12$ & $0 \cdot 18$ & -0.06 \\
\hline Dietary Na density (mg/MJ) & $-0 \cdot 13$ & $-0 \cdot 20$ & $-0 \cdot 15$ & $0 \cdot 10$ & $-0 \cdot 20$ & -0.02 & -0.05 & $-0 \cdot 11$ \\
\hline Dietary $\mathrm{Na}: \mathrm{K}$ ratio & -0.34 & $-0 \cdot 17$ & $0 \cdot 14$ & $0 \cdot 30$ & -0.02 & $0 \cdot 14$ & $-0 \cdot 17$ & 0.00 \\
\hline BMI $\left(\mathrm{kg} / \mathrm{m}^{2}\right)$ & 0.01 & -0.09 & $0 \cdot 13$ & -0.07 & -0.04 & 0.03 & 0.01 & -0.08 \\
\hline Waist circumference $(\mathrm{cm})$ & -0.06 & $-0 \cdot 11$ & $0 \cdot 11$ & $-0 \cdot 10$ & -0.09 & 0.06 & 0.03 & -0.08 \\
\hline Systolic blood pressure $(\mathrm{mmHg})$ & $-0 \cdot 12$ & $-0 \cdot 11$ & 0.01 & 0.02 & -0.02 & 0.03 & 0.04 & -0.02 \\
\hline Diastolic blood pressure $(\mathrm{mmHg})$ & -0.09 & -0.07 & 0.00 & 0.04 & 0.05 & -0.03 & 0.08 & 0.01 \\
\hline Urinary $\mathrm{Na}(\mathrm{mg})$ & 0.03 & -0.08 & $0 \cdot 14$ & 0.09 & -0.02 & 0.08 & 0.06 & -0.06 \\
\hline
\end{tabular}


In the context of dietary guidelines for fat SFA and NMES, PC2 (chips, meat products and eggs) was correlated with high fat and high energy density, while a hot drinks/ confectionery/cakes pattern (PC4 in combined analysis) was correlated with a diet high in SFA and NMES. Of the patterns correlated with high Na intake, only PC3 (bread, fat spread and cheese) was also correlated with high $\mathrm{Na}$ density and high $\mathrm{Na}: \mathrm{K}$ ratio. By contrast three other patterns (health-conscious, breakfast cereals and milk, and chicken and rice) had other features, apart from low salt concentration, that are conducive to better health. PC1 is similar to the DASH diet ${ }^{(18)}$ and consistent with dietary guidelines for SFA and NMES. It may also have an impact on energy density that could be beneficial in terms of obesity prevention. In the same way, the breakfast cereals and milk pattern was correlated with low $\mathrm{Na}: \mathrm{K}$ ratio and relatively low $\mathrm{Na}$ density and NMES, while breakfast cereals also make important contributions to intakes of carbohydrate, NSP and micronutrients.

The SACN guidelines on salt continue to present a challenge given the current composition of the British diet, while the achievability of multiple guidelines is even more problematic. The present analysis would suggest that there may be more compatibility between salt, fat and SFA, than between salt and NMES. The dietary reference values for fat, SFA, NMES and salt were originally conceived as population targets rather than maxima for individuals and it may be unrealistic to expect individuals to attain them. The $10 \%$ reduction in $\mathrm{Na}$ intakes since this NDNS was conducted in 2000/2001 is encouraging, but it is unclear to what extent this is inequitably distributed between health-conscious individuals and others, and how the balance in consumption between salt in processed foods and salt added in cooking or at the table may have shifted. Further research is required to examine how changes in food composition and choice have impacted nutrient intakes (including micronutrient intakes) for consumers with different food habits and lifestyles.

\section{Acknowledgements}

The NDNS was jointly funded by the Department of Health and the Food Standards Agency. The authors acknowledge funding from the Food Standards Agency for preliminary analysis under project N08023 and The Kellogg's Company for costs of the extended analysis reported here. Authors S.G. and M.A. are independent consultants in nutrition who have received remunerations from industry for research, scientific reviews and lectures. S.G. was responsible for data analysis and interpretation and drafting and correcting the manuscript. M.A. contributed additional intellectual and practical input. The authors are also grateful to the anonymous reviewers for their helpful observations and comments.

\section{References}

1. Department of Health (1994) Nutritional Aspects of Cardiovascular Disease. Report on Health and Social Subjects no. 46. London: HMSO.

2. Scientific Advisory Committee on Nutrition (2003) Salt and Health. London: HMSO.

3. Sacks FM, Svetkey LP, Vollmer WM et al. (2001) Effects on blood pressure of reduced dietary sodium and the Dietary Approaches to Stop Hypertension (DASH) diet. DASH-Sodium Collaborative Research Group. $N$ Engl J Med 344, 3-10.

4. He FJ \& MacGregor GA (2004) Effect of longer-term modest salt reduction on blood pressure. Cochrane Database Syst Rev issue 3, CD004937.

5. Hooper L, Bartlett C, Davey Smith G et al. (2002) Systematic review of long term effects of advice to reduce dietary salt in adults. BMJ 325, 628

6. He FJ \& MacGregor GA (2002) Effect of modest salt reduction on blood pressure: a meta-analysis of randomized trials. Implications for public health. J Hum Hypertens 16, 761-770.

7. Jurgens G \& Graudal NA (2004) Effects of low sodium diet versus high sodium diet on blood pressure, renin, aldosterone, catecholamines, cholesterols, and triglyceride. Cochrane Database Syst Rev issue 1, CD004022.

8. Graudal NA, Galloe AM \& Garred P (1998) Effects of sodium restriction on blood pressure, renin, aldosterone, catecholamines, cholesterols, and triglyceride: a metaanalysis. JAMA 279, 1383-1391.

9. Midgley JP, Matthew AG, Greenwood CM et al. (1996) Effect of reduced dietary sodium on blood pressure: a meta-analysis of randomized controlled trials. JAMA 275, $1590-1597$.

10. Alam S \& Johnson AG (1999) A meta-analysis of randomised controlled trials (RCT) among healthy normotensive and essential hypertensive elderly patients to determine the effect of high salt $(\mathrm{NaCl})$ diet of blood pressure. J Hum Hypertens 13, 367-374.

11. Cook NR, Cutler JA, Obarzanek E et al. (2007) Long term effects of dietary sodium reduction on cardiovascular disease outcomes: observational follow-up of the trials of hypertension prevention (TOHP). BMJ 334, 885-888.

12. Perry IJ \& Beevers DG (1992) Salt intake and stroke: a possible direct effect. J Hum Hypertens 6, 23-25.

13. He FJ \& MacGregor GA (2009) A comprehensive review on salt and health and current experience of worldwide salt reduction programmes. J Hum Hypertens 23, 363-384.

14. British Nutrition Foundation (2004) Salt in the Diet. London: BNF.

15. Henderson L, Irving K, Gregory J et al. (2003) The National Diet and Nutrition Survey: Adults Aged 19 to 64 years. vol. 3: Vitamin and Mineral Intake and Urinary Analytes. London: TSO/Office for National Statistics.

16. Food Standards Agency (2009) Salt reduction targets, 2009. http://www.food.gov.uk/news/newsarchive/2009/may/ salttargets (accessed May 2009).

17. Food Standards Agency (2008) Dietary sodium levels surveys, 2008. http://www.food.gov.uk/science/dietarysurveys/urinary (accessed July 2008).

18. Appel LJ, Moore TJ, Obarzanek E et al. (1997) A clinical trial of the effects of dietary patterns on blood pressure. DASH Collaborative Research Group. N Engl J Med 336, $1117-1124$.

19. Sharma S (1996) Applied Multivariate Techniques. New York: John Wiley \& Sons, Inc.

20. Afifi AA, Clark VA \& May S (2004) Principal components analysis. In Computer-aided Multivariate Analysis, th ed. pp. 369-390 [C Chatfield, M Tanner and J Zidek, editors]. Boca Raton, FL: Chapman \& Hall/CRC. 
21. Hoare J, Henderson L, Bates C et al. (2004) The National Diet and Nutrition Survey: Adults Aged 19 to 64 years. vol. 5: Summary Report. London: TSO/Office for National Statistics.

22. Hu FB, Rimm EB, Stampfer MJ et al. (2000) Prospective study of major dietary patterns and risk of coronary heart disease in men. Am J Clin Nutr 72, 912-921.

23. Field A (2000) Exploratory factor analysis. In Discovering Statistics using SPSS for Windows, pp. 423-470 [DB Wright, editor]. London: SAGE Publications.

24. Osler M, Heitmann BL, Gerdes LU et al. (2001) Dietary patterns and mortality in Danish men and women: a prospective observational study. Br J Nutr 85, 219-225.

25. Heidemann C, Schulze MB, Franco OH et al. (2008) Dietary patterns and risk of mortality from cardiovascular disease, cancer, and all causes in a prospective cohort of women. Circulation 118, 230-237.

26. Ambrosini GL, Oddy WH, Robinson M et al. (2009) Adolescent dietary patterns are associated with lifestyle and family psychosocial factors. Public Health Nutr 12, 1807-1815.
27. Pryer JA, Nichols R, Elliott P et al. (2001) Dietary patterns among a national random sample of British adults. J Epidemiol Community Health 55, 29-37.

28. Aranceta J, Perez-Rodrigo C, Ribas L et al. (2003) Sociodemographic and lifestyle determinants of food patterns in Spanish children and adolescents: the enKid study. Eur J Clin Nutr 57, Suppl. 1, S40-S44.

29. Schulze MB, Hoffmann K, Kroke A et al. (2001) Dietary patterns and their association with food and nutrient intake in the European Prospective Investigation into Cancer and Nutrition (EPIC) Potsdam study. Br J Nutr 85, 363-373.

30. Schulze MB, Hoffmann K, Kroke A et al. (2003) Risk of hypertension among women in the EPIC-Potsdam study: comparison of relative risk estimates for exploratory and hypothesisoriented dietary patterns. Am J Epidemiol 158, 365-373.

31. Togo P, Heitmann BL, Sorensen TI et al. (2003) Consistency of food intake factors by different dietary assessment methods and population groups. Br J Nutr 90, 667-678.

32. Lau C, Glumer C, Toft U et al. (2008) Identification and reproducibility of dietary patterns in a Danish cohort: the Inter99 study. Br J Nutr 99, 1089-1098.

\section{Appendix 1}

Food consumption (mean, g/d) according to salt intake group: adults aged 19-64 years (n 1724), National Diet and Nutrition Survey (2000/2001)

\begin{tabular}{|c|c|c|c|c|c|c|c|c|}
\hline \multirow[b]{3}{*}{ Food $(g / d)$} & \multicolumn{4}{|c|}{ Men } & \multicolumn{4}{|c|}{ Women } \\
\hline & \multicolumn{3}{|c|}{ Salt intake group } & \multirow[b]{2}{*}{$\begin{array}{c}\text { Multiple } \\
\text { comparison test }\end{array}$} & \multicolumn{3}{|c|}{ Salt intake group } & \multirow[b]{2}{*}{$\begin{array}{c}\text { Multiple } \\
\text { comparison test }\end{array}$} \\
\hline & $\begin{array}{c}1 \\
(<6 \mathrm{~g} / \mathrm{d})\end{array}$ & $\begin{array}{c}2 \\
(6-8 g / d)\end{array}$ & $\begin{array}{c}3 \\
(\geq 8 \mathrm{~g} / \mathrm{d})\end{array}$ & & $\begin{array}{c}1 \\
(<6 \mathrm{~g} / \mathrm{d})\end{array}$ & $\begin{array}{c}2 \\
(6-8 g / d)\end{array}$ & $\begin{array}{c}3 \\
(\geq 8 \mathrm{~g} / \mathrm{d})\end{array}$ & \\
\hline$n$ & 134 & 249 & 383 & & 571 & 286 & 101 & \\
\hline Pasta & 21 & 23 & 36 & $1,2<3$ & 22 & 28 & 24 & $1<2$ \\
\hline Rice & 32 & 31 & 32 & & 20 & 24 & 33 & $1<3$ \\
\hline Pizza & 8 & 12 & 18 & $1,2<3$ & 6 & 10 & 11 & $1<2$ \\
\hline Other cereal products & 4 & 5 & 5 & & 4 & 5 & 5 & \\
\hline Bread & 68 & 101 & 152 & $1<2<3$ & 66 & 94 & 121 & $1<2<3$ \\
\hline Breakfast cereal & 16 & 31 & 40 & $1<3$ & 22 & 32 & 38 & $1<2,3$ \\
\hline Biscuits, cakes \& pastries & 22 & 35 & 47 & $1<2<3$ & 23 & 37 & 46 & $1<2<3$ \\
\hline Puddings, yoghurt \& ice cream & 24 & 44 & 47 & $1<2<3$ & 39 & 51 & 50 & $1<2$ \\
\hline Milk \& cream & 172 & 212 & 269 & $1,2<3$ & 188 & 225 & 230 & $1<2,3$ \\
\hline Cheese & 9 & 15 & 22 & $1<2<3$ & 12 & 16 & 18 & $1<2,3$ \\
\hline Eggs & 15 & 22 & 24 & & 13 & 20 & 18 & $1<2$ \\
\hline Fat spreads & 8 & 12 & 19 & $1<2<3$ & 8 & 11 & 16 & $1<2<3$ \\
\hline Bacon/ham & 9 & 15 & 25 & $1<2<3$ & 8 & 14 & 18 & $1<2<3$ \\
\hline Red meat & 56 & 55 & 66 & & 40 & 44 & 50 & \\
\hline Chicken \& turkey & 49 & 61 & 66 & $1<3$ & 43 & 47 & 52 & \\
\hline Burgers \& kebabs & 10 & 11 & 11 & & 5 & 5 & 7 & \\
\hline Sausages & 6 & 11 & 17 & $1<2<3$ & 5 & 6 & 11 & $1,2<3$ \\
\hline Meat pies & 11 & 18 & 23 & & 7 & 13 & 15 & $1<2,3$ \\
\hline Other meat \& offal & 7 & 8 & 14 & & 5 & 5 & 10 & $1,2<3$ \\
\hline Fish & 24 & 37 & 32 & $1<2$ & 28 & 33 & 34 & \\
\hline Vegetables excl. baked beans & 109 & 115 & 124 & & 111 & 135 & 131 & $1<2$ \\
\hline Baked beans & 10 & 15 & 27 & $1,2<3$ & 9 & 14 & 23 & $1<2<3$ \\
\hline Chips \& fried potatoes & 47 & 53 & 58 & & 36 & 40 & 45 & \\
\hline Other potatoes & 49 & 58 & 67 & $1<3$ & 51 & 59 & 61 & \\
\hline Savoury snacks & 4 & 7 & 10 & $1,2<3$ & 5 & 7 & 10 & $1<2<3$ \\
\hline Fruit & 61 & 95 & 105 & $1<2,3$ & 101 & 115 & 99 & \\
\hline Sugar, preserves \& confectionery & 32 & 29 & 33 & & 21 & 24 & 29 & $1<3$ \\
\hline Fruit juice & 48 & 60 & 49 & & 42 & 53 & 57 & \\
\hline Soft drinks & 148 & 173 & 257 & $1,2<3$ & 165 & 212 & 254 & $1<2,3$ \\
\hline Beverages & 702 & 741 & 820 & $1<3$ & 685 & 743 & 742 & \\
\hline Soup & 20 & 22 & 30 & & 21 & 28 & 47 & $1,2<3$ \\
\hline Sauces & 17 & 24 & 34 & $1<2<3$ & 19 & 27 & 30 & $1<2,3$ \\
\hline Alcoholic drinks & 465 & 459 & 540 & & 137 & 138 & 174 & \\
\hline Water & 190 & 243 & 261 & & 300 & 321 & 303 & \\
\hline
\end{tabular}


Appendix 2

Energy-adjusted food consumption (g/MJ) according to salt intake group: adults aged 19-64 years (n 1724), National Diet and Nutrition Survey (2000/2001)

\begin{tabular}{|c|c|c|c|c|c|c|c|c|}
\hline \multirow[b]{3}{*}{ Energy-adjusted food (g/MJ) } & \multicolumn{4}{|c|}{ Men } & \multicolumn{4}{|c|}{ Women } \\
\hline & \multicolumn{3}{|c|}{ Salt intake group } & \multirow[b]{2}{*}{$\begin{array}{c}\text { Multiple } \\
\text { comparison test }\end{array}$} & \multicolumn{3}{|c|}{ Salt intake group } & \multirow[b]{2}{*}{$\begin{array}{c}\text { Multiple } \\
\text { comparison test }\end{array}$} \\
\hline & $\begin{array}{c}1 \\
(<6 \mathrm{~g} / \mathrm{d})\end{array}$ & $\begin{array}{c}2 \\
(6-8 g / d)\end{array}$ & $\begin{array}{c}3 \\
(\geq 8 \mathrm{~g} / \mathrm{d})\end{array}$ & & $\begin{array}{c}1 \\
(<6 \mathrm{~g} / \mathrm{d})\end{array}$ & $\begin{array}{c}2 \\
(6-8 \mathrm{~g} / \mathrm{d})\end{array}$ & $\begin{array}{c}3 \\
(\geq 8 \mathrm{~g} / \mathrm{d})\end{array}$ & \\
\hline$n$ & 134 & 249 & 383 & & 571 & 286 & 101 & \\
\hline Pasta & $3 \cdot 2$ & $2 \cdot 6$ & $3 \cdot 4$ & & $3 \cdot 7$ & $3 \cdot 7$ & $2 \cdot 7$ & \\
\hline Rice & $4 \cdot 3$ & $3 \cdot 6$ & $2 \cdot 9$ & $1>3$ & $3 \cdot 4$ & $3 \cdot 1$ & $3 \cdot 7$ & \\
\hline Pizza & $1 \cdot 2$ & $1 \cdot 3$ & $1 \cdot 7$ & & $1 \cdot 1$ & $1 \cdot 4$ & $1 \cdot 2$ & \\
\hline Other cereal products & $0 \cdot 6$ & 0.5 & 0.5 & & $0 \cdot 7$ & $0 \cdot 6$ & 0.5 & \\
\hline Bread & $10 \cdot 3$ & $11 \cdot 7$ & $13 \cdot 9$ & $3>2,1$ & $11 \cdot 3$ & $12 \cdot 5$ & $13 \cdot 5$ & $3,2>1$ \\
\hline Breakfast cereal & $2 \cdot 4$ & $3 \cdot 3$ & $3 \cdot 6$ & & $3 \cdot 5$ & $4 \cdot 2$ & $4 \cdot 4$ & \\
\hline Biscuits, cakes \& pastries & $3 \cdot 0$ & $3 \cdot 8$ & $4 \cdot 1$ & $3>1$ & $3 \cdot 6$ & $4 \cdot 6$ & 4.9 & $3,2>1$ \\
\hline Puddings, yoghurt \& ice cream & $3 \cdot 6$ & $4 \cdot 8$ & $4 \cdot 2$ & & $6 \cdot 2$ & $6 \cdot 5$ & $5 \cdot 5$ & \\
\hline Milk \& cream & $25 \cdot 5$ & $23 \cdot 7$ & $23 \cdot 8$ & & $31 \cdot 3$ & $29 \cdot 1$ & $26 \cdot 0$ & \\
\hline Cheese & $1 \cdot 4$ & $1 \cdot 7$ & 1.9 & $3>1$ & $2 \cdot 0$ & $2 \cdot 1$ & $2 \cdot 0$ & \\
\hline Eggs & $2 \cdot 2$ & $2 \cdot 5$ & $2 \cdot 1$ & & $2 \cdot 3$ & $2 \cdot 7$ & $1 \cdot 9$ & \\
\hline Fat spreads & $1 \cdot 2$ & $1 \cdot 4$ & $1 \cdot 7$ & $3>2,1$ & $1 \cdot 4$ & $1 \cdot 5$ & $1 \cdot 7$ & $3>1$ \\
\hline Bacon/ham & $1 \cdot 4$ & $1 \cdot 9$ & $2 \cdot 3$ & $3>2,1$ & $1 \cdot 4$ & $1 \cdot 9$ & $2 \cdot 0$ & $3,2>1$ \\
\hline Red meat & $7 \cdot 9$ & $6 \cdot 3$ & $5 \cdot 9$ & $1>2,3$ & $6 \cdot 8$ & $5 \cdot 9$ & $5 \cdot 7$ & \\
\hline Chicken \& turkey & $7 \cdot 4$ & $6 \cdot 9$ & $6 \cdot 0$ & & $7 \cdot 3$ & $6 \cdot 2$ & $5 \cdot 7$ & \\
\hline Burgers \& kebabs & $1 \cdot 5$ & $1 \cdot 2$ & $1 \cdot 0$ & & $0 \cdot 9$ & $0 \cdot 6$ & $0 \cdot 8$ & \\
\hline Sausages & 0.9 & $1 \cdot 3$ & $1 \cdot 6$ & $3>1$ & 0.9 & $0 \cdot 9$ & $1 \cdot 2$ & \\
\hline Meat pies & $1 \cdot 6$ & $2 \cdot 1$ & $2 \cdot 1$ & & $1 \cdot 2$ & $1 \cdot 7$ & $1 \cdot 6$ & \\
\hline Other meat \& offal & $1 \cdot 0$ & $0 \cdot 9$ & $1 \cdot 2$ & & $0 \cdot 9$ & $0 \cdot 6$ & $1 \cdot 1$ & \\
\hline Fish & $3 \cdot 7$ & $4 \cdot 3$ & $3 \cdot 0$ & $2>3$ & $4 \cdot 7$ & $4 \cdot 5$ & $3 \cdot 9$ & \\
\hline Vegetables excl. baked beans & $16 \cdot 1$ & $13 \cdot 2$ & $11 \cdot 4$ & $1>2,3$ & $18 \cdot 6$ & $17 \cdot 7$ & $14 \cdot 6$ & $1>3$ \\
\hline Baked beans & 1.5 & $1 \cdot 8$ & $2 \cdot 5$ & $3>1$ & $1 \cdot 7$ & $2 \cdot 0$ & $2 \cdot 5$ & $3>1$ \\
\hline Chips \& fried potatoes & $7 \cdot 1$ & $6 \cdot 0$ & $5 \cdot 2$ & $1>3$ & $6 \cdot 0$ & $5 \cdot 2$ & 4.9 & \\
\hline Other potatoes & $7 \cdot 2$ & $6 \cdot 8$ & $6 \cdot 2$ & & $8 \cdot 8$ & $7 \cdot 8$ & $6 \cdot 9$ & $1>3$ \\
\hline Savoury snacks & $0 \cdot 6$ & $0 \cdot 7$ & $0 \cdot 9$ & $3>1$ & $0 \cdot 8$ & 0.9 & $1 \cdot 0$ & \\
\hline Fruit & $9 \cdot 4$ & $10 \cdot 4$ & $9 \cdot 5$ & & $16 \cdot 7$ & $15 \cdot 1$ & $11 \cdot 0$ & $1>3$ \\
\hline Sugar, preserves \& confectionery & $4 \cdot 5$ & $3 \cdot 2$ & $2 \cdot 9$ & $1>2,3$ & $3 \cdot 4$ & $3 \cdot 0$ & $2 \cdot 9$ & \\
\hline Fruit juice & $7 \cdot 0$ & $6 \cdot 6$ & $4 \cdot 4$ & $1,2>3$ & $6 \cdot 6$ & $6 \cdot 7$ & $6 \cdot 2$ & \\
\hline Soft drinks & $21 \cdot 4$ & $18 \cdot 8$ & $23 \cdot 2$ & & $27 \cdot 6$ & $28 \cdot 3$ & $27 \cdot 4$ & \\
\hline Beverages & $107 \cdot 6$ & $85 \cdot 3$ & $74 \cdot 8$ & $1>2,3$ & $121 \cdot 1$ & $97 \cdot 5$ & $83 \cdot 4$ & $1>2,3$ \\
\hline Soup & $5 \cdot 0$ & $2 \cdot 7$ & $3 \cdot 0$ & & $4 \cdot 0$ & 3.9 & $5 \cdot 8$ & \\
\hline Sauces & $2 \cdot 4$ & $2 \cdot 8$ & $3 \cdot 1$ & $3>1$ & $3 \cdot 2$ & $3 \cdot 6$ & $3 \cdot 2$ & \\
\hline Alcoholic drinks & $62 \cdot 1$ & $49 \cdot 3$ & $47 \cdot 7$ & & $22 \cdot 1$ & $17 \cdot 6$ & $19 \cdot 2$ & \\
\hline Water & $28 \cdot 8$ & $27 \cdot 5$ & $23 \cdot 9$ & & $53 \cdot 5$ & $42 \cdot 4$ & $34 \cdot 6$ & \\
\hline
\end{tabular}


Appendix 3

Percentage sodium contribution from food groups according to salt intake group (foods ranked in descending order of sodium contribution): adults aged 19-64 years (n 1724), National Diet and Nutrition Survey (2000/2001)

\begin{tabular}{|c|c|c|c|c|c|c|c|c|}
\hline \multirow[b]{3}{*}{ Percentage Na contribution from: } & \multicolumn{4}{|c|}{ Men } & \multicolumn{4}{|c|}{ Women } \\
\hline & \multicolumn{3}{|c|}{ Salt intake group } & \multirow[b]{2}{*}{ Total } & \multicolumn{3}{|c|}{ Salt intake group } & \multirow[b]{2}{*}{ Tota } \\
\hline & $\begin{array}{c}1 \\
(<6 \mathrm{~g} / \mathrm{d})\end{array}$ & $\begin{array}{c}2 \\
(6-8 \mathrm{~g} / \mathrm{d})\end{array}$ & $\begin{array}{c}3 \\
(\geq 8 \mathrm{~g} / \mathrm{d})\end{array}$ & & $\begin{array}{c}1 \\
(<6 \mathrm{~g} / \mathrm{d})\end{array}$ & $\begin{array}{c}2 \\
(6-8 g / d)\end{array}$ & $\begin{array}{c}3 \\
(\geq 8 \mathrm{~g} / \mathrm{d})\end{array}$ & \\
\hline Bread & $20 \cdot 6$ & $21 \cdot 3$ & $22 \cdot 3$ & $21 \cdot 8$ & $20 \cdot 8$ & $20 \cdot 8$ & $20 \cdot 1$ & $20 \cdot 7$ \\
\hline Bacon/ham & $6 \cdot 7$ & $8 \cdot 5$ & $9 \cdot 2$ & $8 \cdot 8$ & $6 \cdot 1$ & $7 \cdot 4$ & $7 \cdot 4$ & $6 \cdot 7$ \\
\hline Chicken \& turkey & $6 \cdot 4$ & $5 \cdot 2$ & $4 \cdot 7$ & $5 \cdot 0$ & $5 \cdot 8$ & 4.9 & $4 \cdot 3$ & $5 \cdot 2$ \\
\hline Sauces & $4 \cdot 3$ & 4.9 & $5 \cdot 0$ & $4 \cdot 9$ & $5 \cdot 1$ & $5 \cdot 6$ & $5 \cdot 0$ & $5 \cdot 3$ \\
\hline Breakfast cereal & $3 \cdot 6$ & $4 \cdot 4$ & $4 \cdot 8$ & $4 \cdot 6$ & $5 \cdot 1$ & $5 \cdot 8$ & $6 \cdot 1$ & $5 \cdot 5$ \\
\hline Red meat & $5 \cdot 9$ & $4 \cdot 0$ & $3 \cdot 6$ & 3.9 & $3 \cdot 8$ & $3 \cdot 4$ & $3 \cdot 7$ & $3 \cdot 7$ \\
\hline Cheese & $3 \cdot 6$ & $3 \cdot 8$ & $3 \cdot 9$ & $3 \cdot 8$ & $4 \cdot 1$ & $3 \cdot 9$ & $3 \cdot 4$ & 3.9 \\
\hline Sausages & $3 \cdot 1$ & 3.5 & $4 \cdot 1$ & $3 \cdot 8$ & $2 \cdot 6$ & $2 \cdot 4$ & $2 \cdot 8$ & $2 \cdot 6$ \\
\hline Biscuits, cakes \& pastries & $3 \cdot 5$ & $4 \cdot 0$ & $3 \cdot 7$ & $3 \cdot 8$ & $3 \cdot 9$ & $4 \cdot 2$ & $4 \cdot 1$ & $4 \cdot 0$ \\
\hline Fish & $3 \cdot 8$ & $4 \cdot 2$ & $3 \cdot 1$ & $3 \cdot 5$ & 4.9 & $4 \cdot 5$ & $4 \cdot 2$ & $4 \cdot 6$ \\
\hline Baked beans & $2 \cdot 8$ & $2 \cdot 9$ & $3 \cdot 7$ & $3 \cdot 4$ & $2 \cdot 8$ & $2 \cdot 8$ & $3 \cdot 4$ & $2 \cdot 9$ \\
\hline Fat spreads & $2 \cdot 9$ & $3 \cdot 0$ & $3 \cdot 5$ & $3 \cdot 3$ & $3 \cdot 1$ & $3 \cdot 1$ & $3 \cdot 3$ & $3 \cdot 1$ \\
\hline Milk \& cream & $4 \cdot 2$ & $3 \cdot 3$ & $2 \cdot 9$ & $3 \cdot 1$ & $4 \cdot 4$ & $3 \cdot 6$ & $2 \cdot 8$ & $3 \cdot 8$ \\
\hline Vegetables excl. baked beans & $3 \cdot \overline{6}$ & $2 \cdot 7$ & $2 \cdot 8$ & $2 \cdot 8$ & $4 \cdot 1$ & $4 \cdot 0$ & $4 \cdot 7$ & $4 \cdot 2$ \\
\hline Meat pies & $2 \cdot 8$ & $3 \cdot 0$ & $2 \cdot 7$ & $2 \cdot 8$ & $1 \cdot 7$ & $2 \cdot 2$ & $2 \cdot 0$ & 1.9 \\
\hline Soup & $2 \cdot 6$ & $2 \cdot 9$ & $2 \cdot 7$ & $2 \cdot 7$ & $3 \cdot 9$ & $4 \cdot 1$ & $5 \cdot 8$ & $4 \cdot 3$ \\
\hline Savoury snacks & $1 \cdot 7$ & $2 \cdot 1$ & $2 \cdot 4$ & $2 \cdot 2$ & $2 \cdot 4$ & $2 \cdot 5$ & $2 \cdot 5$ & $2 \cdot 4$ \\
\hline Pizza & $2 \cdot 3$ & $2 \cdot 1$ & $2 \cdot 2$ & $2 \cdot 2$ & $1 \cdot 8$ & $2 \cdot 0$ & $1 \cdot 6$ & $1 \cdot 8$ \\
\hline Other meat \& offal & $1 \cdot 5$ & 1.5 & $2 \cdot 2$ & $1 \cdot \overline{9}$ & $1 \cdot 3$ & $1 \cdot 1$ & $1 \cdot 6$ & $1 \cdot 3$ \\
\hline Eggs & $1 \cdot 7$ & $2 \cdot 1$ & $1 \cdot 8$ & 1.9 & 1.9 & $2 \cdot 2$ & 1.5 & $2 \cdot 0$ \\
\hline Burgers \& kebabs & $2 \cdot 8$ & $1 \cdot 7$ & $1 \cdot 4$ & $1 \cdot 6$ & $1 \cdot 3$ & $1 \cdot 0$ & $1 \cdot 1$ & $1 \cdot 2$ \\
\hline Alcoholic drinks & $1 \cdot 8$ & $1 \cdot 3$ & $1 \cdot 1$ & $1 \cdot 2$ & 0.5 & $0 \cdot 4$ & $0 \cdot 4$ & 0.4 \\
\hline Pasta & $1 \cdot 1$ & 0.9 & $1 \cdot 2$ & $1 \cdot 1$ & $1 \cdot 1$ & $1 \cdot 3$ & $1 \cdot 0$ & $1 \cdot 2$ \\
\hline Puddings, yoghurt \& ice cream & 0.9 & $1 \cdot 2$ & $0 . \overline{9}$ & $1 \cdot 0$ & 1.5 & 1.5 & $1 \cdot 0$ & $1 \cdot 4$ \\
\hline Rice & 0.6 & $1 \cdot 0$ & 0.9 & 0.9 & 0.9 & $1 \cdot 1$ & $1 \cdot 6$ & $1 \cdot 0$ \\
\hline Other cereal products & $0 \cdot 8$ & 0.9 & $0 \cdot 6$ & $0 \cdot 7$ & $0 \cdot 8$ & $0 \cdot 8$ & 0.7 & 0.8 \\
\hline Chips \& fried potatoes & $0 \cdot 8$ & $0 \cdot 7$ & 0.5 & $0 \cdot 6$ & $0 \cdot 8$ & $0 \cdot 6$ & $0 \cdot 6$ & 0.7 \\
\hline Other potatoes & $0 \cdot 5$ & 0.5 & $0 \cdot 6$ & 0.5 & $0 \cdot 8$ & $0 \cdot 6$ & 0.5 & $0 \cdot 7$ \\
\hline Sugar, preserves \& confectionery & 0.5 & 0.6 & 0.5 & 0.5 & $0 \cdot 6$ & $0 \cdot 6$ & 0.5 & 0.6 \\
\hline Fruit & 0.5 & $0 \cdot 6$ & $0 \cdot 3$ & 0.5 & $0 \cdot 6$ & 0.5 & $0 \cdot 7$ & 0.6 \\
\hline Soft drinks & 0.5 & 0.4 & 0.4 & 0.4 & 0.5 & 0.5 & $0 \cdot 4$ & 0.5 \\
\hline Beverages & $0 \cdot 6$ & 0.5 & $0 \cdot 3$ & $0 \cdot 4$ & 0.5 & 0.5 & $1 \cdot 0$ & 0.6 \\
\hline Fruit juice & $0 \cdot 2$ & $0 \cdot 2$ & $0 \cdot 2$ & $0 \cdot 2$ & $0 \cdot 2$ & $0 \cdot 2$ & $0 \cdot 2$ & 0.2 \\
\hline Water & $0 \cdot 0$ & 0.0 & $0 \cdot 0$ & $0 \cdot 0$ & $0 \cdot 0$ & $0 \cdot 0$ & $0 \cdot 0$ & 0.0 \\
\hline
\end{tabular}

